\title{
Routine histopathological examination of gallbladder specimens after cholecystectomy: Is it time to change the current practice?
}

\author{
Banu Karapolat ${ }^{1}($ ID) \\ ${ }^{1}$ Clinic of General Surgery, Kanuni Training and Research Hospital, Trabzon, Turkey
}

Cite this article as: Karapolat B. Routine histopathological examination of gallbladder specimens after cholecystec tomy: Is it time to change the current practice? Turk J Surg 2020; 36 (1): 117-118.

\section{Corresponding Author}

Banu Karapolat

E-mail: banukarapolat@hotmail.com

Received: 21.12 .2018

Accepted: 04.01.2019

Available Online Date: 18.03.2020

o Copyright 2020 by Turkish Surgical Society Available online at www.turkjsurg.com

DOI: 10.5578/turkjsurg.4409
Dear Editor,

Recently, we have read with great interest the article by Benkhadoura et al. entitled "Routine histopathological examination of gallbladder specimens after cholecystectomy: Is it time to change the current practice?" published in the "Turkish Journal of Surgery" (1). First, I congratulate the authors for this successful study and would like to mention some points regarding their article.

It is stated in the article that other than $4(0.11 \%)$ cases that had preoperative or intraoperative diagnosis of malignity, gallbladder carcinoma was not diagnosed through histopathological examination in any of the 3423 gallbladder specimens after cholecystectomy. Therefore, the authors defend that not sending gallbladder specimens to pathology, which were taken from the areas with very low incidence of gallbladder carcinoma in patients who had no prior diagnosis of malignity, would be a safe and more cost-effective practice that would reduce the workload of the pathologists and that it does not appear to compromise patient outcome.

Postcholecystectomy syndrome can be defined as a syndrome where the symptoms such as right upper quadrant pain, dyspepsia, vomiting, and jaundice that had been present in some of the patients who underwent cholecystectomy start to occur again and the causes of which may include formation of residual gallbladder and residual cystic duct stump stone, recurrent/retained common bile duct stone and cystic duct stump remnant. In a cholecystectomy study involving 5820 patients conducted by El Nakeeb et al., residual gall bladder and residual cystic duct stump stone have been found in 21 patients and all patients have undergone open or laparoscopic completion cholecystectomy to relieve symptoms and avoid complications (2). In another study conducted by Shirah et al., postcholecystectomy syndrome has been encountered in 272 patients out of 1374 (incidence 19.8\%) who had cholecystectomy due to gallstone diseases. From these patients, 26 (9.6\%) has had recurrent common bile duct stone, 22 (8.1\%) had retained common bile duct stone and 11 (4\%) had cystic duct stump remnant. Endoscopic retrograde cholangiopancreatography, endoscopy, papillotomy, stone extraction and stenting have been administered to 48 of these patients with recurrent/retained common bile duct stone, the small retained stones have been removed endoscopically in 4 patients with cystic duct stump remnant, and the stumps have been shortened by way of laparoscopic repair in the 7 remaining patients (3). Since same symptoms usually recur in such patients and new invasive interventions or cholecystectomy are administered to them once again, a question like "Have they not removed my 
gallbladder in my first operation?" may come to the minds of these patients. This thought will not only weaken their beliefs in the surgical team, but also cause a number of medicolegal problems to arise. For these reasons, we think that sending the removed gallbladder specimens to histopathological examination after cholecystectomy will constitute an evidence of the procedure performed during the operation and will prevent possible medicolegal problems.

\section{REFERENCES}

1. Benkhadoura M, Elshaikhy A, Eldruki S, Elfaedy O. Routine histopathological examination of gallbladder specimens after cholecystectomy: is it time to change the current practice? Turk J Surg 2019;35(2):86-90. [CrossRef]

2. El Nakeeb A, Ezzat H, Askar W, Salem A, Mahdy Y, Hussien A, et al. Management of residual gallbladder and cystic duct stump stone after cholecystectomy: a retrospective study. Egypt J Surg 2016;35:391-7. [CrossRef]

3. Shirah BH, Shirah HA, Zafar SH, Albeladi KB. Clinical patterns of postcholecystectomy syndrome. Ann Hepatobiliary Pancreat Surg 2018;22(1):52-7. [CrossRef] 